\title{
Russland blir til. Fra vikingene til Ivan den grusomme
}

\author{
Halvor Tjønn \\ Oslo: Dreyer 2015 \\ 490 sider. ISBN 9788282651271
}

Anmeldt av Pål Kolstø [professor, Institutt for litteratur, områdestudier og europeiske språk, Universitetet i Oslo, pal.kolsto@ilos.uio.no]

Halvor Tjønns fremstilling av Russlands tidlige historie, Russland blir til, er en ruvende bok på ikke mindre enn 490 sider. Det betyr at forfatteren kan boltre seg $\mathrm{i}$ detaljer og bringe oss nærmere inn på aktørene enn de fleste tilsvarende bøker. Boken er også velskrevet, og forfatteren behersker stoffet svært godt. Faktafeil er det svært få av, så vidt jeg kunne bedømme.

Tjønn drøfter underveis en del punkter som historikerne er uenige om, og kommenterer også noen av kildenes pålitelighet, men stilen i boken er likevel først og fremst episk fortellende snarere enn analytisk. Forbildet er (etter forfatterens eget utsagn) Carl Grimbergs store populære verdenshistorie, og kanskje også den russiske 1800-talls-historikeren Nikolaj Karamzin som Tjønn i hvert fall har hentet mye av det halv-anekdotiske stoffet fra. I lange partier fungerer denne stilen svært godt, aller best i kapitlene om Ivan den grusomme, en særdeles fargerik hersker som nærmest innbyr til slik fremstilling. Ivans mange groteske handlinger giør kapitlene om ham til rene thrilleren, for ikke å si grøsser-romanen.

Med en så overveldende detalirikdom er det lett for leseren å miste oversikten, men Tjønn er åpenbart klar over den faren og gjør sitt beste for å hindre at det skjer. Han gir små sammendrag og «opphentinger» underveis, av typen «som vi så» og «som det er beskrevet ovenfor». Disse hadde kanskje fungert enda bedre dersom de også var blitt utstyrt med kryssreferanser og en kjapp parentes der det ble oppgitt på hvilke sider dette var beskrevet tidligere. Boken er også utstyrt med et stikkordregister der man vil gjenfinne de fleste av aktørene i boken, så man kan slå opp når man lurer på «hvilken Ivan/Dmitrij/Andrej er det nå egentlig snakk om her?» Derfor er det beklagelig at navneregisteret til tider er feilaktig. Når Tjønn på side 324 skriver at «i januar 1483 ble det, som skildret ovenfor, i Moskva inngått giftermål mellom Stefan [den store, av Moldavia] og Ivan [III]s datter Jelena (som altså ikke må forveksles med hans datter av samme navn)...», da må jeg innrømme at akkurat hvordan denne Jelena Stefanovna kom inn i bildet, det hadde jeg nok glemt og trengte å få gjenoppfrisket. Men dessverre, stikkordregisteret hjalp meg ikke, snarere tvert imot: Det var riktignok ikke mindre enn fire referanser til henne, men ikke på noen av de 
sidene som var oppgitt, var hun nevnt, og jeg måtte ty til Wikipedia for å komme inn i historien igjen.

En tommelfingerregel for en anmelder er man ikke skal etterlyse det man skulle ønsket hadde vært tatt med, og ikke fant. Det er enhver forfatters privilegium å skrive den bok han eller hun vil. Når jeg likevel våger meg ut på den galeien, er det fordi jeg synes bokens tittel lover mer enn den holder. Den antyder at vi vil få presentert en bred fremstilling av de fleste sider ved livet i Russland fra begynnelsen og frem til 1600-tallet. Men i realiteten handler bok kun om fremveksten av staten Russland, og enda snevrere: om herskerne, altså fyrstene og deres slekt, samt deres motstandere. En mer dekkende og presis tittel kunne derfor vært Russlands herskere fra vikingene til Ivan den grusomme, eller ganske enkelt Rjurik-dynastiet. Flere historikere har tidligere skrevet populære fremstillinger av Huset Romanov - det andre russiske dynastiet men ingen har, så vidt jeg vet, skrevet rjurikenes saga, før altså Tjønn gjør det. Med en slik tittel hadde også det sterke aktørfokuset - alle slagscenene, giftemålene og så videre - blitt mer forståelig.

Jeg tror ikke boken hadde behøvd å bli mindre populær eller lesverdig dersom Tjønn hadde lagt større vekt på sosiale, kulturelle og religiøse forhold i gamle Russland. Slik det er nå får vi noen spredte opplysninger om bøndene og byborgernes liv i forskjellige kapitler, mens kirken behandles $i$ et eget kapittel som opptar snaue 16 av bokens 460 tekstsider. Dette kapitlet har undertittelen «Russlands sjel» - en karakteristikk jeg synes er ganske dekkende når det gjelder middelalderens Russland. Men er «sjelen» altså ikke viktigere enn som så? Ideen om «Moskva som det tredje Rom» opptar mye av plassen på disse 16 sidene - åpenbart fordi dette dreier seg om statens historie like mye som om kirken, og det er staten som står i fokus for Tjønn. Derimot er for eksempel Nil Sorskij og Josef av Volokolamsk og den viktige striden mellom de to munkeretningene som disse representerte - «ikke-besitterne» og «besitterne» - ikke nevnt overhodet. «Ikke-besitterne» mente at klostrene ikke skulle eie verdslig gods og gull, men tapte $\mathrm{i}$ denne striden, noe som sterkt kom til å prege den russiske ortodoksien - og faktisk også den russiske staten - i de neste århundrene.

Kanskje fordi kirkekapitlet er så snaut og/eller fordi Tjønn er lite interessert i teologi, blir det han skriver om kirken til tider misvisende. Det er ikke riktig at den ortodokse kirke bare godtar gjengifte dersom ens ektefelle dør, det er en generell adgang til to (men ikke flere) skilsmisser. Det er selvfølgelig en smakssak om man som Tjønn mener at den ortodokse kirkes messe er mer «formfullendt og praktfull» enn den katolske, men det blir direkte galt når det hevdes at ortodoksien «helt og fullstendig avviser muligheten for (...) å forstå Gud og Guds budskap». Selvsagt lærer den ortodokse om Guds budskap til menneskene. Det Tjønn åpenbart sikter til, er den ortodokse apofatiske teologi, som sier at Gud er «ufattbar». Men dette er etter de ortodokse kirkefedrenes lære bare én av to mulige tilnærminger til Gud, den andre er den katafatiske teologi, som nettopp forklarer oss om Guds egenskaper og vesen. For øvrig var den apofatiske teologi kjent og anerkjent også i Vest-kirken (da under navnet «Via negativa»). 
Med andre ord, selv om Tjønn har skrevet en verdifull og lesverdig bok om Russlands herskere frem til 1600-tallet, og Bjørn Nistad nettopp har publisert en fin liten bok om eldre russisk politisk idehistorie, så venter vi fortsatt på en populær bok om Russlands «sjel»: teologi, kirkeliv, klostrenes viktige samfunnsbidrag, religiøs kultur og kunst og fromhetsliv blant vanlige troende i middelalderen. 